\title{
Model Creativity Learning Meningkatkan Keterampilan Berpikir Kreatif dan Tanggung Jawab Pada Mata Pelajaran IPA
}

\author{
Ni Ketut Kris Primayonita1, I Gusti Ayu Tri Agustiana², I Nyoman Laba Jayanta ${ }^{3}$ \\ 1,2,3 Prodi Pendidikan Guru Sekolah Dasar, Universitas Pendidikan Ganesha \\ Singaraja, Indonesia
}

e-mail: krisprimayonita26@gmail.com, triagustiana.pgsdundiksha@gmail.com, laba.jayanta@undiksha.ac.id

\begin{abstract}
Abstrak
Keterampilan berpikir kreatif dan tanggung jawab siswa masih sangat sulit ditumbuhkan karena keterbatasan waktu pembelajaran di sekolah yang mengakibatkan penerapan keterampilan berpikir kreatif dan tanggung jawab siswa pada proses pembelajaran kurang optimal. Adapun tujuan penelitian ini untuk mengetahui pengaruh model Creativity Learning terhadap keterampilan berpikir kreatif dan tanggung jawab siswa. Jenis penelitian ini adalah quasi-experiment, dengan rancangan yang digunakan non-equivalen post-test only control group design. Populasi dalam penelitian ini berjumlah 8 kelas yang terdiri dari 186 orang siswa. Teknik pengambilan sampel pada penelitian adalah Random Sampling dengan jumlah sampel 61 orang siswa. Data di analisis dengan menggunakan statistik Inferensial yaitu Uji Manova. Hasil penelitian menunjukan bahwa terdapat pengaruh yang signifikan keterampilan berpikir kreatif siswa kelas IV pada mata pelajaran IPA dibuktikan bahwa nilai signifikan yang diperoleh 0.000 lebih kecil dari 0.05 maka dapat disimpulkan bahwa model pembelajaran Creativity Learning berpengaruh terhadap keterampilan berpikir kreatif dan tanggung jawab siswa. Model creativity learning merupakan gabungan dari tiga model pembelajaran yaitu model inkuiri, PBL, dan BBL. Model ini mengarahkan siswa menyelesaikan persamasalahan dengan cermat dan kreatif, sehingga siswa terlibat aktif dalam proses pembelajaran. Berdasarkan hasil analisis tersebut model creativity learning sangat cocok diterapkan untuk meningkatkan keterampilan berpikir kreatif dan tanggung jawab siswa.
\end{abstract}

Kata kunci: berpikir kreatif, tanggung jawab, Creativity Learning

\begin{abstract}
Creative thinking skills and student responsibilities are still very difficult to grow because of limited learning time at school which results in the application of creative thinking skills and student responsibilities to the learning process less than optimal. The purpose of this study was to determine the effect of the Creativity Learning model on creative thinking skills and student responsibilities. This type of research is a quasi-experiment, with the design used is non-equivalent post-test only control group design. The population in this study amounted to 8 classes consisting of 186 students. The sampling technique in the study was Random Sampling with a total sample of 61 students. Data were analyzed using Inferential Statistics, the Manova Test. The results showed that there was a significant influence on the creative thinking skills of Grade IV students in science subjects proved that the significant value obtained 0,000 was smaller than 0.05 , so it can be concluded that the Creativity Learning learning model affected the creative thinking skills and student responsibility. The creativity learning model is a combination of three learning models, namely the inquiry model, PBL, and BBL. This model directs students to solve problems carefully and creatively, so students are actively involved in the learning process. Based on the results of the analysis the creativity learning model is very suitable to be applied to improve creative thinking skills and student responsibilities.
\end{abstract}

Keywords: creative thinking, responsibility, creativity learning 


\section{Pendahuluan}

Pembelajaran tematik atau pembelajaran terpadu merupakan sebuah konsep pembelajaran yang melibatkan beberapa mata pelajaran untuk menciptakan pengalaman yang bermakna pada peserta didik (Hidayah, 2015). Pembelajaran tematik juga mengajarkan dan menerapkan sikap sosial kepada siswa yang berkaitan atau berlandaskan Pancasila dan UUD 1945 yang tertuang dalam mata pelajaran Pendidikan Pancasila dan Kewarganegaraan. Selain Pendidikan dan Kewarganegaraan sikap sosial juga dapat tercermin dalam berbagai mata pelajaran, salah satunya yaitu mata pelajaran IPA.

IPA adalah ilmu yang mempelajari tentang fenomena alam dan segala sesuatu yang ada dialam dapat disebut sebagai ilmu tentang alam. IImu yang mempelajari peristiwa-peristiwa yang terjadi di alam ini (Purbosari, 2016). IPA pada dasarnya merupakan sebuah produk serta proses, IImu pengetahuan alam adalah proses mencari tahu keadaan alam sekitar secara sistematis, jadi IPA dapatdiartikanpenguasaan konsep (Mariya, 2019). Pembelajaran IPA pada jenjang pendidikan Sekolah Dasar (SD) bertujuan agar siswa menguasai pengetahuan, fakta, prinsip, proses penemuan, serta memiliki sikap ilmiah yang akan bermanfaat bagi siswa dalam proses tentang diri sendiri ataupun lingkungan sekitar (Sapriati \& Dkk, 2014). Mata pelajaran IPA saling berkorelasi dengan menggali ilmu penegetahuan tentang alam secara terperinci sehingga penemuan IPA tidak hanya terfokus pada pengetahuan yang berupa fakta, konsep, atau prinsip juga merupakan suatu penemuan (Agustiana \& Dkk, 2013). IPA merupakan proses yang digunakan untuk mempelajari objek studi, menemukan dan mengembangkan produk-produk sains, dan sebagai aplikasi, berdasarkan teori-teorinya, IPA dapat memberi kemudahan bagi kehidupan. Selain menumbuhkan dan mengembangkan produk-produk sains, mata pelajaran IPA, siswa juga dituntut untuk memiliki sikap sosial yang baik untuk memunculkan interaksi yang baik bersama teman sejawatnya pada saat proses pembelajaran berlangsung.

Sikap sosial diajarkan sejak dini melalui jenjang pendidikan formal, salah satunya yaitu jenjang sekolah dasar untuk menciptakan interaksi yang baik antara siswa dan teman sejawatnya, maupun dengan orang lain. Salah satu sikap sosial yang menciptakan interaksi yang baik adalah sikap tanggung jawab, baik dalam kelompok ataupun di luar kelompok. Tanggung jawab merupakan suatu kegiatan yang mampu menerima konsekuensi untuk segala kegiatan/tindakan maupun setiap katayang dilontarkan (Rolina, 2014). Sikap tanggung jawab dalam kelompok dapat menumbuhkan interaksi yang baik antar teman maupun antar siswa dengan guru. Tanggung jawab dimaknai sebagai kepribadian manusia berupa kesadaran terhadap diri sendiri serta pengalaman emosional yang dapat dirasakan oleh orang lain, serta berusaha mewujudkan perilaku menerima segala konsekuensi atas tindakan (Eliasa, 2014). Guru membantu siswa memahami peran dan tanggung jawabnya dalam proses pembelajaran dengan menjadi partner in study, melibatkan siswa dalam menggali ilmu pengetahuan, menanamkan sikap positif dalam proses pembelajaran (Voinea \& T., 2014). Melalui sikap tanggung jawab dalam kelompok juga nantinya dapat membantu peserta didik mengorganisir masalah dan kegiatan dalam kelompok, sehingga nantinya akan menciptakan hubungan yang baik dalam sebuah kelompok, bukan hanya itu, peserta didik dituntut bertanggung jawab dan mampu mengemban tugas yang diberikan dalam kelompok.

Selain sikap tanggung jawab, yang perlu siswa kembangkan adalah kemampuan siswa dalam mengembangkan ide kreatif atau kreatifitas siswa. Create (mencipta) adalah suatu kemampuan yang paling tinggi yang dimiliki oleh seseorang dalam taksonomi Bloom setelah mengingat memahami/ mengerti (Nuryani, 2019). Create merupakan ciri-ciri dari seseorang yang berpikir kreatif. Dengan membangun ide kreatif, siswa akan mampu berpikir cepat, luwes, dan tanggap dalam menghadapi permasalahan di kelas. Berpikir kreatif merupakan proses berpikir untuk mengembangkan dan menemukan sebuah ide atau hasil yang orisinil, estetis, dan konstruktif yang berhubungan dengan penggunaan konsep (Dewi, 2012). Siswa dapat memberikan gagasan dan inovasi baru dalam mengembangkan ide dalam proses pembelajaran. Keterampilan berpikir kreatif adalah sebuah keterampilan berpikir yang menuntun individu untuk mengatasi kemampuan dari diri sendiri dan mencari solusinya serta berorientasi terhadap keputusan yang dibuat (Tilaar, 2012). Keterampilan berpikir kreatif 
adalah tindakan atau kemampuan yang harus dikembangkan melalui proses dalam pemecahan masalah dengan mengemukakan ide/gagasan yang dimilikinya (Widiastini \& Dkk, 2018). Keterampilan berpikir kreatif memiliki peran yang sangat penting dalam mengembangkan diri siswa khususnya dalam pembelajaran IPA untuk memecahkan masalah yang dihadapi pada masa yang akan dating (Tumurun \& Dkk, 2006). Keterampilan berpikir kreatif yang dikembangkan di sekolah dasar dapat disesuaikan dengan tingkat kognitif siswa dan kemampuan siswa yang masih pada tahap oprasional konkret. Apabila siswa telah dilatih untuk berpikir kreatif sejak sekolah dasar, maka manfaatnya akan dapat dirasakan oleh siswa hingga ke jenjang pendidikan selanjutnya. Untuk mengembangkan keterampilan berpikir kreatif siswa dalam proses pembelajaran dapat melalui berbagai mata pelajaran yang diajarkan. Salah satu mata pelajaran yang dapat mengembangkan keterampilan berpikir kreatif siswa adalah mata pelajaran IPA. IPA sangat diperlukan dalam kehidupan sehari-hari dalam memecahkan permasalahan yang dihadapi manusia.

Secara umum proses belajar mengajar cenderung berpusat pada guru dan kurang melibatkan siswa dalam proses pembelajaran yang menyebabkan komunikasi siswa masih berjalan satu arah dan siswa kurang berpartisipasi aktif dalam proses pembelajaran. Selain itu, permasalahan yang sering terjadi adalah siswa kurang disiplin dalam mengerjakan tugas, hal ini mempengaruhi sikap tanggung jawab pada diri sendiri kurang, pengembangan kemampuan berpikir kreatif siswa masih dibatasi dan belum optimal, sehingga siswa belum dapat mengembangkan potensinya, dan guru belum menggunakan model yang inovatif serta cenderung menggunakan metode ceramah dan metode penugasan. Pembatasan masalah pada penelitian ini dilakukan karena keterbatasan waktu penelitian. Adapun pembatasan masalah ini terbatas pada penggunaan model pembelajaran yang belum inovatif, pembelajaran menjadi kurang menarik, kurangnya kebebasan siswa dalam mengembangkan kemampuan berpikir kreatif, dan tanggung jawab.

Namun kenyataan yang telah ditemukan di Gugus 1 Kecamatan Buleleng bahwa masih sangat sulit menumbuhkan keterampilan berpikir kreatif siswa dan rasa tanggung jawab dalam diri anak, ini dikarenakan masih tingginya rasa ingin menang sendiri pada anak dan keterbatasan waktu pembelajaran di sekolah. Hal ini yang mengakibatkan proses pembelajaran belum berlangsung sesuai harapan yang mengakibatkan penerapan keterampilan berpikir kreatif dan menanamkan tanggung jawab kepada siswa sekolah dasar belum optimal. Kenyataan ini mengakibatkan rasa tanggung jawab siswa sulit tumbuh. Siswa yang ingin mengembangkan ide kreatif, guru cenderung membatasi karena kurangnya waktu pembelajaran sehingga sulit untuk menerima ide atau gagasan yang diberikan oleh siswa untuk hal-hal baru, sehingga siswa merasa terbatas dalam mengembangkan ide yang ingin diungkapkan. Kejadian ini mengakibatkan siswa tidak ingin mengembangkan kemampuan berpikir kreatif tentang pembelajaran dan cenderung mengikuti alur pembelajaran yang telah ditentukan oleh guru.

Sedangkan hasil wawancara dengan wali kelas, guru cenderung membatasi karena kurangnya waktu pembelajaran sehingga sulit untuk menerima ide atau gagasan yang diberikan oleh siswa untuk hal-hal baru, sehingga siswa merasa terbatas dalam mengembangkan ide yang ingin diungkapkan. Pada proses pembelajaran siswa juga dituntut untuk menghafal materi yang disampaikan tanpa dituntut materi yang diingat oleh siswa. Kebanyakan di SD Gugus I Banyuning masih menerapkan teacher centered, interaksi yang terjadi pada proses pembelajaran masih berjalan satu arah. Kemudian proses pembelajaran yang diterapkan guru masih kurang menggunakan model baru yang lebih inovatif dan cara pengemasan materinya kurang mendukung untuk meningkatkan keterampilan berpikir kreatif siswa karena dalam proses pembelajaran metode yang digunakan lebih banyak dengan ceramah.

Kurangnya pengemasan materi yang inovatif dan kreatif untuk mendukung dalam meningkatkan nilai siswa dapat mengakibatkan keterbatasan pemahaman materi. Semakin banyak materi yang dibelajarkan melalui metode ceramah mengakibatkan siswa mudah bosan dan jenuh, sehingga materi yang diajarkan tidak dipahami. Dengan permasalahan ini dapat mempengaruhi keterampilan berpikir kreatif siswa dan tanggung jawab siswa. Hal ini 
dibuktikan berdasarkan penilaian tengah semester siswa siswa di kelas pada mata pelajaran IPA masih dibawah KKM.

Tabel 1. Nilai Rata-rata Penilaian Tengah Semester Mata Pelajaran IPA Kelas IV SD di Gugus I Kecamatan Buleleng

\begin{tabular}{llccccc}
\hline No & Nama Sekolah & $\begin{array}{c}\text { Jumlah } \\
\text { Siswa }\end{array}$ & KKM & Tuntas & $\begin{array}{c}\text { Tidak } \\
\text { Tuntas }\end{array}$ & $\begin{array}{c}\text { Nilai } \\
\text { Rata-rata }\end{array}$ \\
\hline 1 & $\begin{array}{l}\text { SD Negeri 1 } \\
\text { Banyuning }\end{array}$ & 31 orang & 68 & 11 & 19 & 65,13 \\
\hline 2 & $\begin{array}{l}\text { SD Negeri 2 } \\
\text { Banyuning }\end{array}$ & 28 orang & 68 & 6 & 22 & 65,93 \\
\hline 3 & $\begin{array}{l}\text { SD Negeri 3 } \\
\text { Banyuning }\end{array}$ & 19 orang & 70 & 6 & 13 & 66,79 \\
\hline 4 & $\begin{array}{l}\text { SD Negeri 4 } \\
\text { Banyuning }\end{array}$ & 16 orang & 68 & 7 & 9 & 66,88 \\
\hline 5 & $\begin{array}{l}\text { SD Negeri 5 } \\
\text { Banyuning }\end{array}$ & 32 orang & 68 & 12 & 20 & 65,13 \\
\hline 6 & $\begin{array}{l}\text { SD Negeri 6 } \\
\text { Banyuning }\end{array}$ & 16 orang & 70 & 6 & 10 & 67,31 \\
\hline 7 & $\begin{array}{l}\text { SD Negeri 7 } \\
\text { Banyuning }\end{array}$ & 14 orang & 70 & 2 & 12 & 66,21 \\
\hline 8 & $\begin{array}{l}\text { SD Negeri 8 } \\
\text { Banyuning }\end{array}$ & 30 orang & 68 & 6 & 24 & 66,16 \\
\hline Jumlah & 186 orang & & 56 & 130 & 66,19 \\
\hline
\end{tabular}

(Sumber: Wali Kelas IV di SD Gugus 1 Kecamatan Buleleng)

Berdasarkan Tabel 1 diatas dari 186 orang siswa masih 130 orang siswa yang berada dibawah KKM, ini merupakan satu masalah yang harus diatasi. Dilihat dari nilai rata-rata kelas sebesar 66,19 dikonvensikan dalam tabel konvensi Penilaian Acuan Patokan (PAP) menurut (Agung, 2014) maka dapat dikategorikan sedang, ini juga merupakan satu masalah yang harus diatasi. Berdasarkan hasil observasi tersebut rendahnya nilai kreatifitas siswa pada mata pelajaran IPA salah satu penyebabnya adalah kurangnya pengemasan model pembelajaran yang inovatif untuk digunakan. Apabila hal ini berlanjut, keterampilan berpikir kreatif dan tangung jawab siswa tidak akan terwujud sesuai harapan.

Salah satu model yang dapat diterapkan dalam mata pelajaran IPA untuk mengembangkan keterampilan berpikir kreatif serta tanggung jawab siswa adalah model pembelajaran Creativity Learning. Model ini adalah salah satu model yang baru dikembangkan. Model Creativity Learning ini merupakan penggabungan tiga model pembelajaran menjadi satu, yaitu model Inquiri, Brain Based Learning (BBL), Problem Based Learning (PBL). Model pembelajaran Creativity Learning dirancang berlandasakan dan disesuaikan dengan teori kontruktivisme dalam belajar. Guru dituntut untuk terampil dalam memotivasi dan bertanya untuk merangsang siswa lebih banyak menggali informasi (Agustiana \& Dkk, 2019). Model Creativity Learning sangat tepat apabila diterpakan di sekolah dasar, karena pada model ini menekankan siswa untuk aktif dan berpartisipasi pada proses pembelajaran untuk menemukan informasi sendiri. Model Creativity Learning siswa ditekankan bertanggung jawab terhadap permasalahan yang akan dipecahkan dalam suatu kelompok belajar dan bekerjasama untuk pemecahan masalah yang dihadapi kelompok dengan kemampuan yang berbeda antara siswa satu dan siswa lain. Oleh karena itu, maka akan terjadi interaksi dua arah antara siswa dan guru. Model pembelajaran Creativity Learning merupakan sebuah pembelajaran yang bersifat langsung tetapi sangat efektif untuk membantu siswa mengembangkan keterampilan berpikir kreatif dan mandiri. Pada model pembelajaran Creativity Learning, siswa secara aktif mengeluarkan ide-ide kreatif dalam memecahkan 
masalah, serta melakukan investigasi untuk menemukan solusi dari masalah kreatif (Agustiana \& Dkk, 2019).

Terdapat beberapa kelebihan model pembelajaran yang mengacu pada proses pembelajaran kontruktivis seperti memberikan kesempatan kepada siswa untuk membangun pengetahuan dan pemahaman baru yang didasarkan pada pengalaman nyata, mampu mengintegrasikan pembelajaran dengan situasi yang sering dialami oleh mahasiswa dalam kehidupan sehari-hari. Hal ini dapat dilakukan dengan menyediakan tugas atau permasalahan yang berkaitan dengan aplikasi IPA dalam kehidupan sehari-hari, siswa untuk menggali ide kreatif menemukan sebuah klaim-klaim sebagai bentuk jawaban permasalahan yang diberikannya dan dalam kerja kelompok diberikan kebebasan dalam mengklaim gagasan sebanyak mungkin (Agustiana \& Dkk, 2019). Sintak model creativity learning terdiri dari tujuh fase meliputi, fase orientasi, fase penggalian ide kreatif, fase penyelidikan, fase elaborasi, fase menyajikan ide kreatif, fase evaluasi, dan fase implementasi (Agustiana \& Dkk, 2019).

Berdasarkan uaraian yang telah dipaparkan, untuk mengoptimalkan keterampilan berpikir kreatif dan sikap tanggung jawab siswa, maka dilakukanlah penelitian dengan menerapkan model pembelajaran yang inovatif, yaitu model pembelajaran Creativity Learning Melalui Model Pembelajaran Creativity Learning terhadap Keterampilan Berpikir Kreatif dan Tanggung Jawab Siswa Kelas IV pada Mata Pelajaran IPA di Gugus I Kecamatan Buleleng, guru dapat meningkatkan keterampilan berpikir kreatif dan tanggung jawab siswa dengan menekankan pengalaman langsung kepada siswa melalui model yang inovatif dalam memahami pentingnya mengembangkan siswa memiliki keterampilan berpikir kreatif dan sikap tanggung jawab dalam kelompok untuk mencapai tujuan yang diinginkan dan menciptakan interaksi yang baik antar teman, peserta didik dengan guru, maupun peserta didik dengan seluruh anggota sekolah.

Penelitian ini didukung oleh (Agustiana, 2015), bahwa implementasi model pembelajaran OPEMES terbukti sangat efektif digunakan untuk meningkatkan keterampilan berpikir kreatif. Pernyataan tersebut didasarkan pada kemampuan dalam pemberian orientasi, penggalian ide kreatif dan penyajian karya, yang semi itu menjadi tangga-tangga motivasi untuk meningkatkan berpikir kreatif mahasiswa. Penelitian ini juga didukung oleh (Agustiana, 2017), dengan hasil penelitian yang menyatakan bahwa, keterampilan berpikir kreatif siswa dapat meningkat dengan penerapan model pembelajaran inkuiri dalam kelas. Keterampilan berpikir kreatif bisa dikembangkan pada pembelajaran IPA melalui beberapa metode atau model yang relevan, salah satunya Creativity Learning (Fauziah, 2011). (Widiana \& Dkk, 2017) dengan hasil penelitian menyatakan bahwa model pembelajaran dan gaya kognitif memiliki pengaruh positif terhadap hasil belajar dan kemampuan berpikir kreatif siswa. Pada penelitian ini juga menyatakan bahwa terdapat perbedaan yang signifikan hasil belajar antara kelompok siswa yang telah dibelajarkan dengan model pembelajaran berbasis otak dan kelompok siswa yang dibelajarkan dengan model pembelajaran konvensional. penelitian yang dilakukan menggunakan model Creativity Learning yang merupakan gabungan dari model PBL, BBL, serta Inkuiri, mengukur aktivitas tanggung jawab siswa, serta tempat pelaksanaan penelitian dilakukan SD di Gugus I Banyuning sedangkan pada penelitian yang dilakukan Widiana dkk, menggunakan model pembelajaran berbasis otak.

Berdasarkan pemaparan di atas, maka dilaksanakan penelitian eksperimen dengan judul "Model Creativity Learning Meningkatkan Keterampilan Berpikir Kreatif dan Tanggung Jawab pada Mata Pelajaran IPA", adapun tujuan diadakan penelitian ini adalah untuk mengetahui pengaruh model creativity learning terhadap keterampilan berpikir kreatif dan tanggung jawab siswa kelas IV pada mata pelajaran IPA. Selain itu belum ada penelitian menggunakan model creativity learning, model ini merupakan gabungan dari 3 model pembelajaran yaitu model inkuiri, PBL, dan BBL. Adapun keterbatasan dalam penelitian ini yaitu, yang pertama penelitian ini terfokus pada pemecahan permasalahan yang berkaitan dengan fenomena alam sekitar dan kreatifitas siswa kelas IV di SD Gugus I Kecamatan Buleleng, kedua pembahasan dalam penelitian ini terbatas hanya materi percobaan, ketiga penelitian ini menggunakan model creativity learning dengan 7 fase, dan waktu pengimplementasiannya terbatas. 


\section{Metode}

Rancangan yang akan digunakan dalam penelitian ini adalah rancangan eksperimen semu (quasi- eksperimen design). Rancangan ini tidak melakukan manipulasi terhadap subjek dan tidak dapat mengontrol variabel yang memengaruhi eksperimen secara ketat. Penelitian yang digunakan adalah penelitan eksperimen semu. Dikarenakan tidak semua variabel eksperimen dapat diatur dan dikontrol secara ketat, maka penelitian ini dikategorikan penelitian eksperimen semu (quasi experiment). Desain penelitian ini mengikuti desain penelitian eksperimen non-equivalen post-test only control group design. Populasi yang merupakan keseluruhan kelas IV SD di Gugus 1 Banyuning dengan jumlah 8 kelas yang terdiri dari 186 siswa. Teknik pengambilan sampel adalah Random Sampling dilakukan dengan cara undian. Teknik ini hanya dapat dilakukan apabila anggota populasi homogen atau setara. Setelah melakukan uji kesetaraan denggan menggunakan analisis varians 1 jalur (Anava A) dengan menggunakan Microsoft Excel for Windows maka akan dilanjutkan dengan teknik random sampling, pengambilan sampel secara acak dengan undian. Dengan demikian didapatkan komposisi anggota sampel kelas experimen siswa kelas IV SD Negeri 1 Banyuning dengan jumlah 31 siswa dan kelas kontrol siswa kelas IV SD Negeri 8 Banyuning dengan jumlah 30 siswa.

Pengumpulan data dalam penelitian ini meliputi keterampilan berpikir kreatif siswa dan tanggung jawab. Kegiatan pengumpulan data dilaksanakan pada siswa kelas IV SD Gugus 1 Banyuning menjadi anggota sampel. Data yang diperlukan dalam penelitian ini dikumpulkan dengan metode tes berbasis konten untuk keterampilan berpikir kreatif dan non-test (lembar observasi/pengamatan kegiatan siswa pada proses pembelajaran) untuk tanggung jawab dengan mengukur kemampuan siswa memimpin, bekerja sama, berpartisipasi aktif, menghargai orang lain dan menyampaikan pendapat dalam proses pembelajaran. Metode analisis data dalam penelitian ini menggunakan metode analisis statistik deskriptif yaitu menghitung rata-rata (mean) dan standar deviasi kemudian dikonsultasikan dengan PAIT (penilaian acuan ideal teoritik) untuk mengetahui kategori keterampilan berpikir kreatif dan tanggung jawab siswa pada mata pelajaran IPA dan statistik inferensial berupa uji prasyarat (normalitas, homogenitas, dan korelasi antar variabel) untuk menghitung normalitas dan homogenitas data digunakan bantuan SPSS versi 17.0 dan uji korelasi antar variabel terikat dilakukan dengan formula statistic Product Moment oleh Pearson (Pearson's Product Moment) analisisnya dilakukan dengan hitungan manual. Dilanjutkan uji manova dengan keputusan dianalisis nilai Pillai Trace, Wilk Lambda, Hotelling Trace, Roy's dan F test. Untuk melihat apakah mempengaruhi atau tidak mempengaruhi keterampilan berpikir kreatif dan tanggung jawab siswa antara siswa pada kelompok eksperimen dan siswa pada kelompok kontrol yang diberi perlakuan berbeda dapat dilihat nilai signifikan dari Pillai Trace, Wilk Lambda, Hotelling Trace, Roy's dan F test terhadap signifikansi 0.05 .

\section{Hasil dan Pembahasan}

Skor Keterampilan Berpikir Kreatif dan Tanggung Jawab siswa kelas eksperimen selanjutnya dikonversikan skala lima dengan penilaian acuan ideal teoritik (PAIT) untuk menentukan tinggi rendahnya sebaran data. Sesuai dengan kriteria penskoran, maka ditentukan skor maksimal ideal adalah 100 dan skor minimum ideal adalah 0. Sebelum dikonversikan skala lima dengan penilaian acuan ideal teoritik (PAIT) data skor keterampilan berpikir kreatif dan tanggung jawab dianalisis dengan statistik deskriptif. Hasil uji statistik deskriptif keterampilan berpikir kreatif dan tanggung jawab perhitungan ukuran sentra (mean) dan ukuran sebaran data (standar deviasi) memberikan hasil seperti disajikan dalam tabel 2.

Tabel 2. Rekapitulasi Hasil Analisis Statistik Deskriptif Keterampilan Berpikir Kreatif dan Tanggung Jawab

\begin{tabular}{lllll}
\hline Variabel & Kelas & Mean & Standar Deviasi & N \\
\hline Keterampilan Berpikir Kreatif & Eksperimen & 79.832 & 4.2025 & 31 \\
& Kontrol & 71.800 & 4.8594 & 30 \\
& Total & 75.882 & 6.0529 & 61 \\
\hline Tanggung Jawab & Eksperimen & 3.0065 & 0.35957 & 31
\end{tabular}




$\begin{array}{llll}\text { Kontrol } & 2.5267 & 0.25855 & 30 \\ \text { Total } & 2.7705 & 0.39427 & 61\end{array}$

Berdasarkan analisis statistik deskriptif pada tabel di atas, maka dapat disimpulkan bahwa rata-rata keterampilan berpikir kreatif dan tanggung jawab adalah skor berpikir kreatif kelas control dengan mean 71.800 , dengan standar deviasi 4.8594 , dengan ukuran sampel 30 , skor berpikir kreatif kelas eksperimen dengan mean 79.832, dengan standar deviasi 4.2025, dengan ukuran sampel 31, skor tanggung jawab kelas control dengan mean 2.5267, dengan standar deviasi 0.25855 , dengan ukuran sampel 30 , dan skor tanggung jawab kelas eksperimen dengan mean 3.0065, dengan standar deviasi 0.35957 , dengan ukuran sampel 31.

Setelah melakukan uji statistik deskriptif dilanjutkan dengan analisis statistik inferensial, yaitu uji prasyarat dan uji manova. Yang pertama adalah uji normalitas dapat dilihat pada tabel 3

Tabel 3

Uji Normalitas Sebaran Data dan Homogenitas Varian

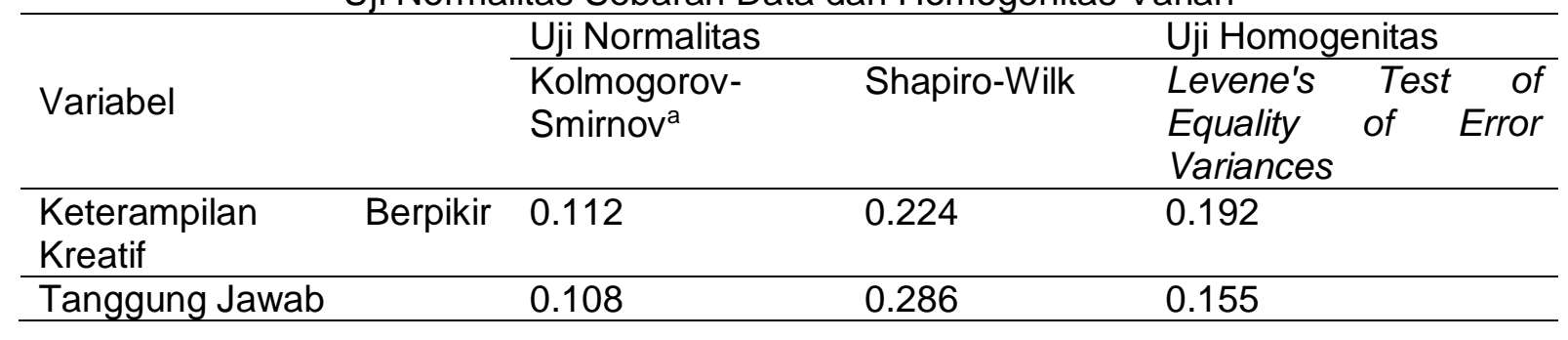

Berdasarkan data hasil analisis Tests of Normality di atas nilai Sig. skor tanggung jawab yaitu 0.075 pada kolmogorov-smirnov, dan 0.286 pada shapiro-wilk. Ini berarti lebih besar dari 0.05 , karena lebih besar dari 0.05 , maka skor tanggung jawab berdistribusi normal. Untuk skor berpikir kreatif diperoleh nilai sig. Pada kolmogorov-smirnov yaitu 0.054 dan pada shapiro-wilk adalah 0.224 , ini berarti lebih besar dari 0.05 . Karena lebih besar dari 0.05 , maka skor berpikir kreatif berdistribusi normal.

Berdasarkan hasil analisis Levene's Test of Equality of Error Variances menunjukan bahwa skor keterampilan berpikir kreatif yaitu 0.192, ini berarti lebih besar dari 0.05, karena lebih besar dari 0.05 , maka skor keterampilan berpikir kreatif antara kelas kontrol dan kelas eksperimen adalah sama atau homogeny. Untuk hasil analisis skor tanggung jawab diperoleh nilai Sig. sebesar 0.115, ini berarti lebih besar dari 0.05 , karena lebih besar dari 0.05 , maka skor tanggung jawab antara kelas kontrol dan kelas eksperimen adalah sama atau homogeny. Dengan demikian dapat disimpulkan bahwa variabel keterampilan berpikir kreatif dan tanggung jawab adalah homogen.

Uji korelasi bertujuan untuk mengetahui tingkat keeratan hubungan antar variabel yang dinyatakan dengan koefisien korelasi (r). Jika nilai signifikansi< 0,05 , maka berkorelasi, dan jika nilai signifikansi $>0,05$ maka tidak berkorelasi. Dari hasil perhitungan nilai pearson korelasi keterampilan berpikir kreatif dan tanggung jawab yaitu 0,366 $>0,05$ jadi dapat disimpulkan keterampilan berpikir kreatif tidak berkorelasi dengan tanggung jawab.

Bedasarkan hasil uji normalitas sebaran data, uji homogenitas varians, dan uji korelasi antar variabel terikat diketahui bahwa data yang diperoleh kelompok kontrol dan ekspeimen berdistribusi normal, memiliki varians yang homogeny, dan tidak berkorelasi. Karena data yang diperoleh telah memenuhi prasyarat maka uji hipotesis dapat dilakukan dengan menggunakan uji manova. Hasil analisis manova dari data penguasaan keterampilan berpikir kreatif dan tanggung jawab siswa disajikan pada tabel 4. 
Tabel 4. Multivariate Test

\begin{tabular}{llll}
\hline Effect & & Value & Sig \\
\hline \multirow{4}{*}{ Intercept } & Pillai's Trace & 0.997 & 0.00 \\
& Wilks' Lambda & 0.003 & 0.00 \\
\cline { 2 - 4 } & Hotelling's Trace & 393.840 & 0.00 \\
& Roy's Largest Root & 393.840 & 0.00 \\
\hline \multirow{3}{*}{ Kelas } & Pillai's Trace & 0.604 & 0.00 \\
& Wilks' Lambda & 0.396 & 0.00 \\
\cline { 2 - 4 } & Hotelling's Trace & 1.526 & 0.00 \\
& Roy's Largest Root & 1.526 & 0.00 \\
\hline
\end{tabular}

Uji Multivariate digunakan untuk menguji apakah ada pengaruh rata-rata Keteampilan Berpikir Kreatif dan Tanggung jawab dengan menggunakan model Creativity Learning untuk kelas Kontrol dengan kelas Eksperimen. Keputusan dianalisis dengan nilai Pillai Trace, Wilk Lambda, Hotelling Trace, Roy's dan F test. Untuk melihat apakah mempengaruhi atau tidak mempengaruhi dapat dilihat nilai signifikan dari Pillai Trace, Wilk Lambda, Hotelling Trace, Roy's dan F test terhadap signifikansi 0.05 .

Bedasarkan Tabel 4 akan ditentukan model pembelajaran Creativity Learning memiliki pengaruh terhadap keterampilan berpikir kreatif dan tanggung jawab. Hasil semua test kelas (Kontrol dan Eksperimen) nilai signifikan yang diperoleh 0.00 lebih kecil dari 0.05 maka dapat disimpulkan bahwa model pembelajaran Creativity Learning mempengaruhi keterampilan berpikir kreataif dan tanggung jawab siswa. Berdasarkan pernyataan diatas $\mathrm{H}_{0}$ ditolak dan $\mathrm{H}_{1}$ diterima. Jadi dapat ditarik kesimpulan model pembelajaran Creativity Learning memiliki pengaruh yang signifikan terhadap keterampilan berpikir kreatif dan tanggung jawab siswa pada mata pelajaran IPA di SD Gugus 1 Kecamatan Buleleng.

Pada proses pembelajaran dengan menerapkan model Creativity Learning untuk meningkatkan keterampilan berpikir kreatif pada pembelajaran IPA terdiri: 1) Fase orientasi, guru memberikan motivasi kepada siswa dengan memberikan masalah tentang fenomena alam. Terlihat keluwesan (flexibility) siswa menjawab dengan memberikan jawaban-jawaban yang bervariasi. Pernyataan tersebut sesuai dengan pendapat (Harahap, 2019) yang menyatakan flexibility merujuk pada keberhasilan siswa dalam memberikan jawaban atau ide atau solusi yang bervariasi dengan berbagai kategori. Keaslian (originality) meningkat dengan adanya kegiatan orientasi atau pemberian motivasi kepada siswa. Hal ini didukung dengan pernyataan oleh (Gamez \& Dkk, 2016) yang menyatakan originality atau keaslian yaitu kemampuan menghasilkan ide yang unik dan tidak lazim. 2) Fase penggalian ide kreatif, siswa menggali ide sebanyak mungkin untuk meningkatkan kreativitas dalam perumusan hipotesis sehingga dapat memecahkan permasalahan. Siswa merancang hipotesis dan melakukan percobaan. Kegiatan tersebut dapat meningkatkan kelancaran (Fluency). Hal tersebut sejalan dengan pendapat (Harahap, 2019) bahwa kelancaran dapat menghasilkan banyak ide atau gagasan yang relevan yang sesuai dengan permasalahan. 3) Fase penyelidikan, pada fase penyelidikan aspek keterampilan berpikir kreatif yang meningkat adalah keluwesan (flexibility). Hal ini didukung oleh pernyataan (Wijaya \& Dkk, 2016) menyatakan keluwesan adalah kemampuan untuk menghasilkan ide-ide yang variatif, mampu merubah cara pikir yang lama mejadi yang baru dan merubah cara pandang terhadap sesuatu. 4) Fase elaborasi, pada fase elaborasi aspek keterampilan berpikir kreatif yang meningkat adalah aspek elaboration. Siswa mengembangkan gagasan dari pertanyaan yang diajukan. Kegiatan ini meningkatkan keterampilan berpikir kreatif pada aspek elaborasi (elaboration). Pernyataan ini didukung oleh pernyataan (Agustiana \& Dkk, 2019) menyatakan elaborasi yaitu kemampuan dalam mengembangkan gagasan dan menambahkan atau memperinci detai-detail dari suatu subjek. 5) Fase evaluasi, dalam fase evaluasi aspek keterampilan berpikir kreatif yang meningkat adalah aspek evaluasi (evaluation). Fase evaluasi setiap kelompok mampu menilai dan memberikan tanggapan (Agustiana \& Dkk, 2019) menyatakan evaluasi merupakan kemampuan untuk mengambil keputusan yang terbuka. 
Pada proses pembelajaran dengan menerapkan model Creativity Learning untuk meningkatkan tanggung jawab pada pembelajaran IPA terdapat beberapa fase yang sangat berpengaruh dalam proses pembelajaran yaitu: 1) Fase Penggalian Ide Kreatif. Anggota kelompok dapat memilih ketua kelompok yang dijadikan pemimpin untuk mengatur jalannya diskusi, sehingga diskusi dilaksanakan tepat waktu. Hal tersebut sejalan dengan pendapat (Suyidino, 2018) bahwa kepemimpinan merupakan kegiatan yang mengambil peran dan tugas memimpin dalam sebuah kelompok yang berkaitan dengan tugas pendidikan. 2) Fase penyelidikan siswa berpartisipasi aktif dalam kegiatan percobaan. Semua siswa dalam kelompok bekerjasama untuk melakukan percobaan sehingga seluruh anggota kelompok ikut berpartisipasi menyelidiki permasalahan. Hal ini didukung pernyataan (Suyidino, 2018) menyatakan berpartisipasi merupakan kegiatan yang memerlukan kontak mata dan menikuti semua arah kegiatan/tugas yang disampaikan oleh guru dan berpartisipasi aktif dalam tugas tersebut. Kelompok yang lebih dulu selesai melakukan percobaan mendapat nilai yang lebih tinggi sehingga kerja sama kelompok terlihat dalam mengerjakan tugasnya. Kegiatan tersebut mampu meningkatkan sikap tanggung jawab pada aspek kerja sama. Hal tersebut sejalan dengan pendapat (Aziz \& Dkk, 2006) menyatakan kerja sama dalam kelompok diharapkan adanya ikatan positif, saling membantu, saling menolong dan memberikan motivasi, sehingga menimbulkan interaksi positif. 3) Fase menyajikan hasil karya, pada fase ini akan terlihat sikap siswa yang mampu mengargai orang lain dengan melihat kontak mata siswa apakah tertuju dengan siswa yang sedang menyampaikan pendapat. Hal tersebut didukung pernyataan (Widyaningrum \& Prihastari, 2018) menyatakan meyampaikan pendapat merupakan kemampuan dan keinginan individu untuk menyampaikan sesuatu pendapat yang penting berdasarkan pengetahuan dan pemikiran yang dimiliki. 4) Pada fase menyajikan hasil karya aspek sikap tanggung jawab yang juga meningkat adalah aspek menghormati orang lain. Kegiatan ini meningkatkan sikap tanggung jawab pada aspek menghormati orang lain. Hal ini sejalan dengan pendapat (Wardani \& Uyun, 2017) bahwa mengormati orang yang berbicara di depan, sikap menghormati, sopan santun kepada orang yang lebih tua dianggap penting antar sesama umat manusia agar hidupnya selaras dan diterima oleh masyarakat sekitar.

Model creativity learning berpengaruh terhadap keterampilan berpikir kreatif dan tanggung jawab siswa, sejalan dengan pendapat ahli model pembelajaran Creativity Learning adalah sebuah pembelajaran yang bersifat langsung tapi sangat efektif untuk membantu siswa mengembangkan keterampilan berpikir kreatif dan mandiri. Pada model pembelajaran Creativity Learning, siswa secara aktif mengeluarkan ide-ide kreatif dalam memecahkan masalah, serta melakukan investigasi unuk menemukan solusi alternatif dari masalah kreatif, (Agustiana \& Dkk, 2019). Model creativity learning cocok digunakan untuk meningkatkan tanggung jawab siswa. Kesadaran akan tanggung jawab bukan merupakan sikap bawaan atau hereditas, namun perlu ditumbukan melalui kebiasaan. Upaya pembiasaan tanggung jawab perlu dilatih sedini mungkin (Susanti, 2015). Selain meningkatkan tanggung jawab model Creativity Learning dapat meningkatkan keterampilan berpikir kreatif. Hal ini didukung oleh (Nuryani, 2019) Pembelajaran creativity learning memberikan kesempatan kepada siswa untuk mengembangkan keterampilan berpikir kreatif. Model ini sangat cocok diterpkan pada pembelajaran IPA. Tujuan pembelajaran IPA di SD yaitu memiliki pemahaman mengenai disiplin keilmuan dan keterampilan berpikir kreatif serta tanggung jawab dalam menghasilkan sebuah produk yang dapat dijadikan bukti oleh siswa sebagai hasil belajar. Pembelajaran IPA yang dimaksudkan yaitu dalam ranah peserta didik, sebagai kemampuan untuk: 1) mengingat dan mengulang konsep, prinsip, dan prosudur, 2) mengidentifikasi dan memilih, dan 3) menerapkan konsep, prinsip dan prosedur (Agustiana, 2014). Penerapan model Creativity Learning pada kelas eksperimen membuat siswa lebih aktif dan kreatif dalam proses pembelajaran dengan menuntut siswa untuk menyelesaikan permasalahan secara mandiri ataupun berkelompok. Selain itu, siswa terlihat lebih antusias pada saat pemecahan masalah ataupun saat penyelidikan permasalahan sehingga berdampak pada kemapuan berpikir kreatif siswa (Putra \& Dkk, 2016). Siswa juga mampu menerapkan sikap tanggung jawab dengan penyelesaian masalah tepat waktu dan mampu menyajikan hasil karya dengan baik. Saat awal

\footnotetext{
Received 19 April 2020, Accepted 19 Juni 2020; Available online 5 Juli 2020
} 
pembelajaran siswa jadi lebih aktif untuk mengacungkan tangan dan bertanya mengenai hal yang belum dimengerti atau masih membingungkan (Apriliani \& Wangig, 2015).

Berdasarkan hasil penelitian yang dilakukan oleh (Dewi, 2012) menyatakan bahwa hasil Hasil kemampuan berpikir kreatif siswa mengalami peningkatan baik dari siklus I ke II maupun ke III. Hasil perhitungan dengan uji gain diperoleh peningkatan gain $<\mathrm{g}>$ sebesar 0,49 untuk nilai kemampuan berpikir kreatif dari siklus I ke II. Untuk hasil kemampuan berpikir kreatif siswa dari siklus II ke III diperoleh peningkatan gain $<\mathrm{g}>$ sebesar 0,34. Penerapan pembelajaran dengan pendekatan keterampilan proses pada materi kalor dapat meningkatkan hasil belajar dan kemampuan berpikir kreatif siswa. Hal ini juga didukung oleh beberapa penelitian sebelumnya yang relevan seperti: (1) penelitian yang dilakukan oleh (Putri \& Dkk, 2017), hasil penelitian menyatakan bahwa bahwa kemampuan berpikir kreatif siswa padaLKS 1 secara umum memiliki persentase $41 \%$ dengan kategori kemampuan berpikir cukup kreatif dan $31 \%$ dengan kemampuan berpikir kurang kreatif pada LKS 2.(2) penelitian yang dilakukan oleh (Widiana \& Dkk, 2017) hasil penelitian menyatakan bahwa bahwa model pembelajaran dan gaya kognitif berpengaruh positif terhadap hasil belajar dan kemampuan berpikir kreatif siswa. (3) penelitian yang dilakukan oleh (Agustiana, 2017) penerapan model pembelajaran inkuiri dapat meningkatkan keterampilan berpikir kreatif mahasiswa. Hal ini dapat terlihat dari hasil nilai rata-rata keterampilan berpikir kreatif mahasiswa pada siklus I sebesar 32,90 dengan ketuntasan klasikal 41,94\%; pada siklus II sebesar 36,35 dengan ketuntasan klasikal 50,06\%; dan pada siklus III sebesar 50,16 dengan ketuntasan klasikal sebesar $100 \%$.

Dari ketiga peneitian yang telah dipaparkan, maka perlu dilaksanakan penelitian tentang model creativity learning. Adapun kelebihan model creativity learning yang mengacu pada proses pembelajaran kontruktivis seperti memberikan kesempatan kepada siswa untuk membangun pengetahuan dan pemahaman baru yang didasarkan pada pengalaman nyata, mampu mengintegrasikan pembelajaran dengan situasi yang sering dialami oleh mahasiswa dalam kehidupan sehari-hari. Hal ini dapat dilakukan dengan menyediakan tugas atau permasalahan yang berkaitan dengan aplikasi IPA dalam kehidupan sehari-hari, siswa untuk menggali ide kreatif menemukan sebuah klaim-klaim sebagai bentuk jawaban permasalahan yang diberikannya dan dalam kerja kelompok diberikan kebebasan dalam mengklaim gagasan sebanyak mungkin (Agustiana \& Dkk, 2019). Dengan dilakukannya penelitian ini membuktikan bahwa model creativity learning berpengaruh terhadap keterampilan berpikir kreatif dan tanggung jawab.

\section{Simpulan}

Berdasarkan hasil analisis dan pembahasan yang telah ditentukan dapat disimpulkan bahwa terdapat pengaruh rata-rata keteampilan berpikir kreatif dan tanggung jawab dengan menggunakan model Creativity Learning untuk kelas Kontrol dan kelas Eksperimen. Keputusan dianalisis dengan nilai multivariate test. Untuk melihat apakah mempengaruhi atau tidak mempengaruhi dapat dilihat nilai signifikan dari multivariate test dengan signifikansi 0.05. Hasil semua test kelas (Kontrol dan Eksperimen) nilai signifikan yang diperoleh 0.000 lebih kecil dari 0.05 maka dapat disimpulkan bahwa model pembelajaran Creativity Learning mempengaruhi keterampilan berpikir kreataif dan tanggung jawab siswa. Saran yang dapat penulis sampaikan berdasarkan penelitian yang telah dilakukan untuk peneliti lain yang akan melakukan penelitian tentang model pembelajaran Creativity Learning dalam mata pelajaran IPA ataupun mata pelajaran lainnya yang sesuai dengan model Creativity Learning, hendaknya dapat menguasi model terlebih dahulu, memahami kendalakendala dalam penerapan model dalam penelitian ini sehingga dapat dijadikan pertimbangan unuk penerapan perbaikan model Creativity Learning agar hasil penelitian dapat lebih sempurna.

\section{Daftar Pustaka}

Agung, A. A. G. 2014. Buku Ajar Metodologi Penelitian Pendidikan. Singaraja: Aditya 
Media Publishing.

Agustiana, I. G. A. T. 2014. Konsep Dasar IPA Aspek Biologi. Yogyakarta: Ombak.

Agustiana, I. G. A. T. 2015. Model Pembelajaran OPEMES dalam Meningkatkan Keterampilan Berpikir Kreatif Mahasiswa PGSD. Surabaya: Prosiding Seminar Nasional Pendidikan Sains. ISBN: 978-602-72071-0-3, (hlm.1423-1433).

Agustiana, I. G. A. T. 2017. Penerapan Model Pembelajaran Inkuiri untuk Meningkatkan Keterampilan Berpikir Kreatif Mahasiswa PGSD. Surabaya: Prosiding Seminar Nasional Pendidikan Sains PPs Unesa. ISBN: 978-602732290-4, (hlm 1423-1433).

Agustiana, I. G. A. T., \& Dkk. 2013. Konsep Dasar IPA Aspek Fisika dan Kimia. Ombak. Agustiana, I. G. A. T., \& Dkk. 2019. Model Pembelajaran OPPEMEl. Undiksha Press. Apriliani, A., \& Wangig, M. N. 2015. Pengaruh SSP Tematik-Integratif terhadap Karakter Disiplin dan Tanggung Jawab Siswa Kelas III SD. Jurnal Prima Edukasi, Volume 3, Nomor 1.

Aziz, A., \& Dkk. 2006. Penerapan Model Pembelajaran Kooperatif dengan Memanfaatkan Alat Peraga Sains Fisika (Materi Tata Surya) untuk Meningkatkan Hasil Belajar Dan Kerjasama Siswa. Jurnal Pendidikan Fisika Indonesia, Volume 4, Nomor2, (hlm.94-99).

Dewi, N. L. P. K. 2012. Pengaruh Model Pembelajaran Pdeode Terhadap Kemampuan Berpikir Kreatif Dalam Pembelajaran IPA pada Siswa Kelas V SD Laboratorium Undiksha. Jurnal Mimbar PGSD Undiksha.

Eliasa, E. I. 2014. Increasing Valueof Teamwork and Responsibility of the Students Through Games: Integratingeducation Character in Lectures. Procedia-Social and Behavioral Sciences, Volume 123, Nomor 196.

Fauziah, Y. N. 2011. Analisis Kemampuan Guru dalam Mengembangkan Keterampilan Berpikir Kreatif Siswa Sekolah Dasar Kelas V pada Pembelajaran Ilmu Pengetahuan Alam. Jurnal Edisi Khusus, Volume 1, Nomor 1, (hlm.98-106).

Gamez, C. M., \& Dkk. 2016. Developing Preservice Science Teacher' Beliefs about New Approaches to Science Education. Jurnal of Turkish Science Education, Volume 13, Nomor 2, (hlm.123-136).

Harahap, F. 2019. Model Pembelajaran CDR-Po untuk Melatih Keterampilan Berpikir Kreatif Siswa dalam Pembelajaran SAINS SMP. UNESA.

Hidayah, N. 2015. Meningkatkan Hasil Belajar Tematik Integratif Menggunakan Model Demonstrasi pada Siswa Kelas I SDN 82/VII Sei Benteng II. Jurnal Refleksi Edukatika, Volume 8, Nomor2.

Mariya, M. 2019. Keefektifan Model Problem Based Learning untuk Meningkatkan Hasil Belajar IPA. Jurnal Pajar (Pendidikan Dan Pengajaran), Volume 3, Nomor 6, (hlm.1247-1254).

Nuryani, D. 2019. Efektifitas Media Smart Land untuk Meningkatkan Kemampuan Berpikir Kreatif Siswa Sekolah Dasar. Jurnal Mimbar PGSD Undiksha, Volume 7, Nomor 2.

Purbosari, P. M. 2016. Pembelajaran Berbasis Proyek Membuat Ensiklopedia IImu Pengetahuan Alam (IPA) untuk Meningkatkan Academic Skill pada Mahasiswa. Scholaria: Jurnal Pendidikan Dan Kebudayaan, Volume 6, Nomor 3, (hlm.231238).

Putra, R. D., \& Dkk. 2016. No TitlePeningkatan Kemampuan Berpikir Kreatif Siswa melalui Model Pembelajaran Inkuiri Terbimbing pada Siswa Kelas XI MIA 1 SMA Negeri Colomadu Karanganyar Tahun Pelajaran 2015/2016. In Proceeding Biology Education Conference: Biology, Science, Enviromental, and Learning, 
Volume 13, Nomor 1.

Putri, I. W. S., \& Dkk. 2017. Kemampuan Berpikir Kreatif dalam Menyelesaikan Masalah Kesebangunan di SMPN 11 Jember. Jurnal Edukasi, Volume 4, Nomor 3, (hlm.59-62).

Rolina, N. 2014. Developing Responsibility Character for University Student In ECE Through Project Method. Procedia-Social and Behavioral Sciences, Volume 123, Nomor 170.

Sapriati, A., \& Dkk. 2014. Pembelajaran IPA di SD. Universitas Terbuka.

Susanti, R. H. 2015. Meningkatkan Kesadaran Tanggung Jawab Siswa SMP melalui Penggunaan Teknik Klarifikasi Nilai. Jurnal Konseling Indonesia, Volume 1, Nomor 1.

Suyidino. 2017. Effectivenese Of Creative Responsbility Based Teaching (CRBT) Model on Basic Physice Learning to Increase Student's Scientific. Creativity and Responsbility Journal of Baltic Science Education, Volume 17, Nomor 1.

Tilaar, H. A. R. 2012. Pengembangan Kreativitas dan Entrepreneurship Dalam Pendidikan Nasional. PT. Kompas Media Nusantara.

Tumurun, S. wahyu, \& Dkk. 2006. Pengaruh Model Pembelajaran Discovery Learning terhadap Keterampilan Berpikir Kreatif Siswa pada Materi Sifat-Sifat Cahaya. Jurnal Pena IImiah, Volume 1, Nomor 1.

Voinea, M., \& T., P. 2014. Teacher's professional identity in the 21st century Romania. Procedia-Social and Behavioral Sciences.

Wardani, F. L., \& Uyun, Z. 2017. Ngajeni Wong Liyo; Menghormati Orang yang Lebih Tua pada Remaja Etnis Jawa. Jurnal Ilmiah Psikologi, Volume 2, Nomor 2, (hlm.176-183).

Widiana, I. W., \& Dkk. 2017. Pembelajaran Berbasis Otak (Brain Based Learning) Gaya Kognitif Kemampuan Berpikir Kreatif dan Hasil Belajar Mahasiswa. Jurnal Pendidikan Indonesia, Volume 6, Nomor 1.

Widiastini, Y., \& Dkk. 2018. Kemampuan Berpikir Kreatif Siswa pada Pembelajaran Pemecahan Menggunakan Pendekatan Open Ended. Jurnal Pendidikan Matematika, Volume 12, Nomor 2.

Widyaningrum, R., \& Prihastari, E. B. 2018. Implementasi Model Pembelajaran Talking Chips Disertai Media Fotonovela untuk Meningkatkan Sikap Peduli Lingkungan dan Kemampuan Menyampaikan Pendapat Mahasiswa. Premiere Educandum, Volume 8, Nomor 1, (hlm.22-30).

Wijaya, L., \& Dkk. 2016. Analisis Kemampuan Berpikir Kreatif Matematis Siswa SMP Kelas VII Ditinjau dari Tipe Kepribadian. Journal of Mathematics Education, Volume 5, Nomor 2, (hlm.84-91). 